\title{
化粧品におけるスキンケア製郕の役割
}

\section{The Role of Skincare Formulations in Cosmetics}
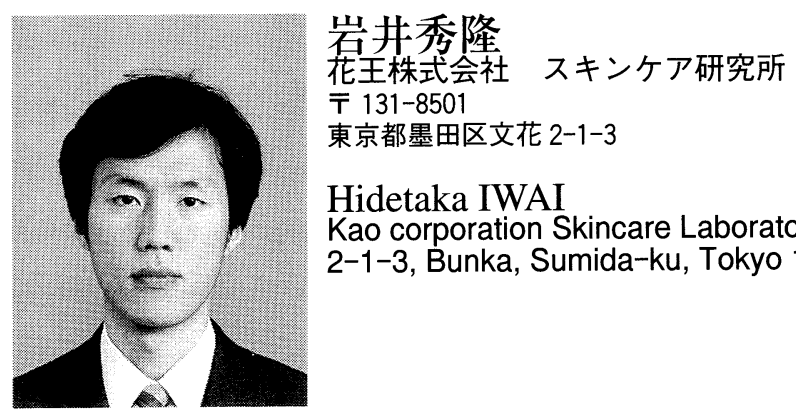

T $131-8501$

東京都墨田区文花 2-1-3

Hidetaka IWAI

Kao corporation Skincare Laboratories

2-1-3, Bunka, Sumida-ku, Tokyo 131-0085

\begin{abstract}
The basic role of skincare formula is moisturization of skin controlling with suitable feeling. Natural moisturizing factor, sebum, and ceramide are nessesary for keeping healthy skin. Skincare products have a role to supply them into stratum corneum. These days study of dermatology is advanced remarkably. Many preventive or treating materials for aging problem of skin; wrinkle, pigmentation etc. are found. Therefore, it becomes more important for skincare product to penetrate them into suitable position of the skin. Skin penetration enhancers are synthesized and mechanical penetration systems are made. But they are not suitable as a cosmetic, because it is not always safety and a simple and easy way. New skincare formula are developed and their characters are investigated. Microemulsion is prepared by physicochemical or mechanical methods. This is transparence and much stable. Additionally, enhance of penetration of materials are expected.
\end{abstract}

Key words: cosmetic, moisture, microemulsion, stratum corneum

\section{1 はじめに}

化粧品に扔いて乳化型製剂は水のヒューメクタント (humectant) と油のエモリエント（emorient）を同時 に与える剤型であり，古くからその使用部位，用途，感 触面から油中水分散型 $(W / O)$ と水中油分散型 $(\mathrm{O} / \mathrm{W})$ を使い分けてきた。

使用感は連続相に大きく影響を受けることから， $\mathrm{W} / \mathrm{O}$ は「油っぽい」感触を与えるため部分使用のスキ ンケア化粧料として, 高い保湿効果を求める場合に使用 されてきた。一方， $\mathrm{O} / \mathrm{W}$ は「のびが良い」「みずみずし い」感触から, 若い世代や夏場のスキンケア化粧料とし ての使い方が多くされてきた。

しかし，近年のびがよく，さっぱりした感触をもった 油剂が開発され, シリコーン油, フッ素油などの炭化水 素系油以外の油剤の乳化が可能な界面活性剂の開発がな された結果 ${ }^{1,2)}$ ，これまで $\mathrm{W} / \mathrm{O}$ 剂型独特の感触とされ てきた油性感をコントロールした W/O が製戍化される ようになってきた。その結果, $\mathrm{W} / \mathrm{O}$ と $\mathrm{O} / \mathrm{W}$ の使い分

連絡者: 岩井秀隆

E-mail : 301560@kastanet.kao.co.jp
けがあいまいになってきた。

最近のスキンケア化粧料は保湿効果を求めるだけでな く, 紫外線防御能や美白効果, しわ改善効果などの機能 の付加が著しい。従って，紫外線吸収剂や美白剤などを 安定に配合する工夫が製剂側に求められる。また，有効 成分がいかに効率上く皮膚に浸透し，効果発現を生み出 すかが製郕開発の基本となりつつある。こうした観点か ら，スキンケア効果の側面からの製剤化についてまとめ てみた。

\section{2 スキンケア製刘の基本的機能}

\section{$2 \cdot 1$ 皮膚の保湿機構}

スキンケアで求められる最も基本の効果は, 皮膚の保 湿である。厳密に言えば，角質層の保湿である。皮膚の 断面を（Fig. 1）に示す。真皮は 60 〜 70\%の水を占めて いるのに対し, 外界と接する角質層は $33 \%$ 程度の水を 含有し, うる扔いのある状態を保っている。冬場の乾燥 期でも，入浴後でも常に一定な状態を維持している。角 質層の厚さは $20 \sim 40 \mu \mathrm{m}$ であるにも関わらず，柔軟性， 伸縮性をもちながら, 外界のあらゆる環境変化に対し一 定の状態を保っている。ラップフィルムほどの厚みにも 


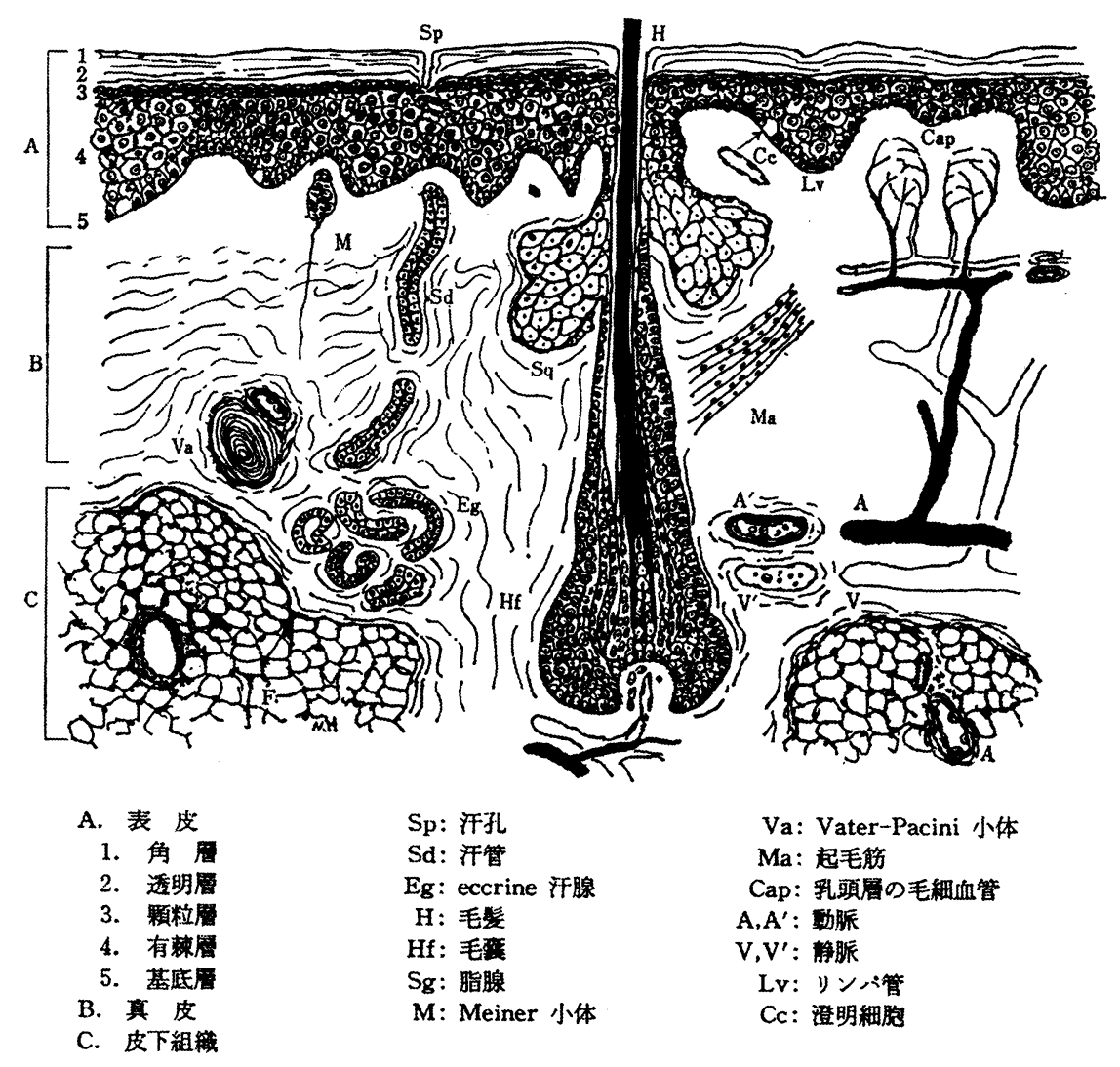

Fig. 1 Cross Section of Human Skin.

かかわらず，こうした機能を有していることは驚異的な ことである。医療分野ではコラーゲンなどの生体高分子 を利用した人工皮虚 (真皮) の研究は進んでいるが ${ }^{3), 4}$ 角質層に相当する合成フィルムの開発は見受けられな い。

角質層が正常な役割を果たすためには，天然保湿因子 (NMF : natutral moisturizing factor), セラミド, 皮脂 膜の 3 つの機能が満たされている必要があることが明ら かにされている5)。従って，3機能のバランスがとられ るようにすることがスキンケアの本質であり，乾燥した 肌に直接的に水分を供給することで肌がうるおい，正常 化されることにはならない。

\subsection{NMF}

NMF 成分は角質細胞内に存在し, NMF 成分の有無 でケラチン分子の運動性が大きく変化し ${ }^{6)}$, 角層の柔軟 性と対応していた（Table 1)。こうした背景を受けて, 水性成分に NMF 成分を配合した処方が調製されてい る。さらにNMF の保水能に着目してアミノ酸系エステ ル油が合成されたり 洗浄剤の開発により NMF の溶出を抑えた洗浄製剂が開 発されている ${ }^{8)}$ 。

\section{$2 \cdot 3$ 皮脂膜}

皮脂膜は皮虐表面を覆い，皮虐内部から蒸散する水分
Table 1 Composition of NMF.

\begin{tabular}{l|r}
\hline \multicolumn{1}{c|}{ 成 } & 分 \\
\hline 組 & 成 \\
\hline PCA 酸類 & $40 \%$ \\
乳酸塩 & $12 \%$ \\
尿素 & $12 \%$ \\
$\mathrm{NH}_{3}$, 尿素, グルコサミン, クレアチニン, & $7 \%$ \\
クエン酸塩 & $1.5 \%$ \\
$\mathrm{Na} 5 \%, \mathrm{Ca} 15 \%, \mathrm{Mg} 1.5 \%, \mathrm{PO}_{4} 0.5 \%$, & $18.5 \%$ \\
$\mathrm{Cl} 6 \%$ & $8.50 \%$ \\
糖, 有機酸, ペプチド, その他 & \\
\hline
\end{tabular}

Table 2 Composition of Sebum.

\begin{tabular}{l|r}
\hline \multicolumn{1}{c|}{ 成 } & 分 \\
\hline コレステリルエステル & 縝 \\
コレステロール & $2.5 \%$ \\
スクワレン & $1.5 \%$ \\
ワックス & $10 \%$ \\
トリグリセライド & $22 \%$ \\
モノ-, ジーグリセライド & $25 \%$ \\
遊離脂肪酸 & $10 \%$ \\
その他 & $25 \%$ \\
\hline
\end{tabular}

を抑える役割をもつ（Table 2)。従って，スキンケアで は最も容易なステップである。油性成分を含む製剤を皮 膚に塗布すると, 水分揮発で乳化が壊れ, 油膜が皮膚表 面に形成されることにより, 皮脂膜機能が現われる。そ の際極性の低い油ほどその効果があることが見出されて 
いる ${ }^{9), 10)}$ 。皮脂膜は厚いほど閉塞性が高くなるため効果 が高まるが, 油独特の感触や, 額や鼻でみられるような テカリや化粧くずれの原因となるため, 必ずしも好まれ なる状態ではない。脂とり紙がブームになったことは記 憶に新しい。また過㮃な皮脂は毛穴を詰まらせ，細菌の 繁殖を起こしにきびなどの炎症の原因にもなっており， 皮脂コントロールが重要な課題となっている。最近で は, 皮脂膜成分が日光紫外線でラジカルや活性酸素を発 生し, 皮䖉細胞の変性をもたらす報告もされている ${ }^{11)} 。$ そうしたことから, 皮脂膜成分に依存した積極的なスキ ンケアはあまりなされていない。

\section{$2 \cdot 4$ セラミド}

セラミドは角質細胞間に脂肪酸, コレステロールとと もに細胞間脂質の主成分の形でラメラ構造を形成して存 在している（Table 3, Fig.2）。このラメラ構造の層間に 水を結合水の形で約 $13 \%$ 程度保持することにより, 柔軟 な状態を維持している ${ }^{12)}$ 。さらに角質細胞同士を接着す る働きも持ち, スケーリング（肌荒れ）防止の役割を果 たしている ${ }^{13)}$ 。

細胞間脂質成分は両親媒性構造なため, 自己会合体形 成能をもつ ${ }^{14)}$ 。細胞間脂質成分がベシクルを形成する報 告もなされている ${ }^{15)}$ 。細胞間脂質が失われた角質層はそ の細胞間に隙間が生じるため, 刺激物質の進入路となっ てしまう。細胞間脂質成分を配合したスキンケア化粧料 はその隙間に浸透し, 本来と同一のラメラ構造を再構築 して，正常な状態に戻してくれる。

鈴木らは細胞間脂質成分が形成するラメラ構造を利用

Table 3 Composition of Intercellular Lipids.

\begin{tabular}{cc}
\hline 成 分 & 組 \\
\hline コレステリルエ成 \\
\hline コレステロール & $10 \%$ \\
スフィンゴ脂質 & $15 \%$ \\
遊離脂肪酸 & $55 \%$ \\
\hline
\end{tabular}

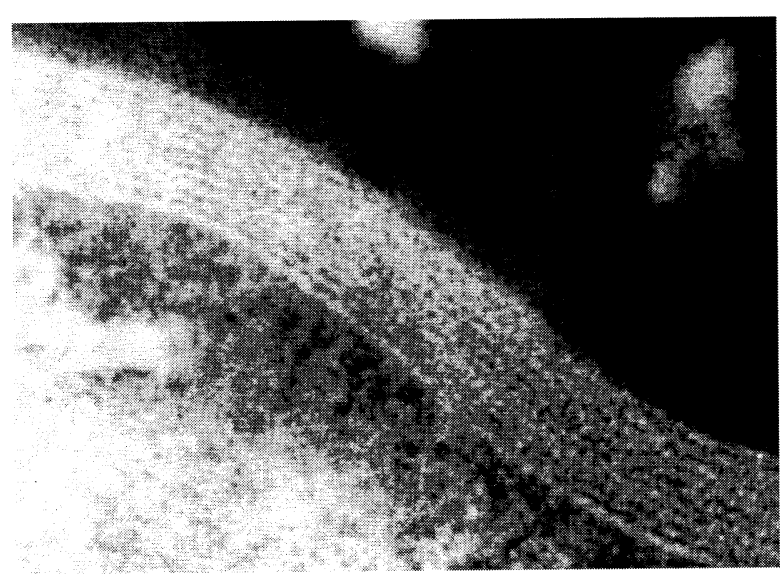

Fig. 2 Lamellar Structure of Intercellular Lipids in Stratum Corneum.

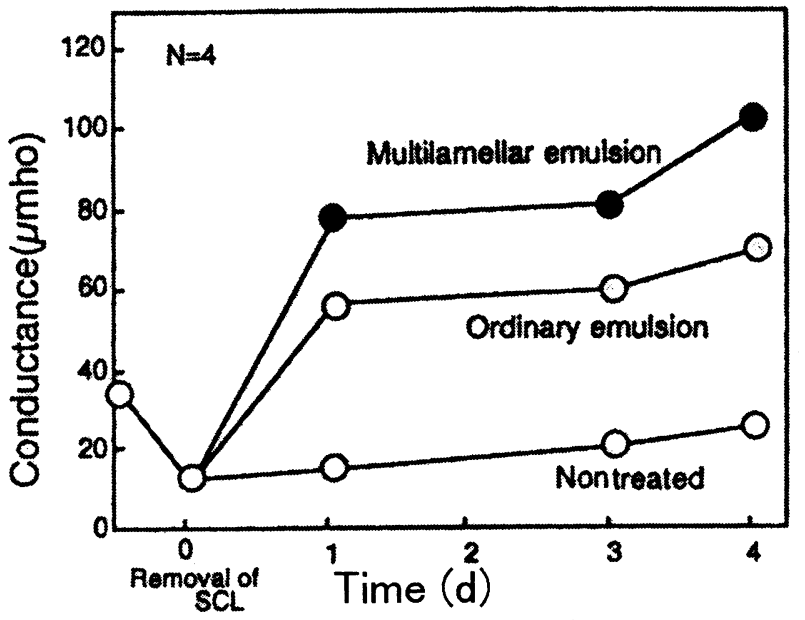

Fig. 3 Recovery of Skin Surface Conductance Values Corresponding to Water-retaining Ability of Stratum Corneum by the Treatment of Emulsions.

してマルチラメラエマルションを調製した。角質細胞間 と同一の集合構造を形成していることから，通常のエマ ルションと比較して優れた荒れ肌改善効果を示すことを 報告している ${ }^{16)}$ (Fig. 3)。

\section{3 スキンケア製㓮と経皮吸収}

\section{$3 \cdot 1$ 経皮吸収の向上}

皮虞の最外層である角層は本来, 外界からの様々な刺 激物質の進入を防御するバリアーとしての働きを持って いる。

こうしたバリアーを薬剂がいかに透過できるかが課題 となる。角質層の浸透ルートは(1)角質細胞間経由, (2)角 質細胞内経由, (3)毛穴経由がある ${ }^{17)}$ (Fig. 4)。医薬品分野 では経皮浸透促進剤の開発がなされている。この促進機 構は(1)脂質構造の変化と流動性の増加(2)角質細胞間脂質 の除去による細胞間隙拡大(3)角質層細胞剥離によるバリ アー機能の減退(4)溶媒中薬物の熱力学的活動度の上昇に 分類される ${ }^{18)}$ 。これまで, Azone $\mathrm{e}^{19)}$ ，ピロチオデカン ${ }^{20)}$ などの浸透促進郕が数多く開発されている。これらは, 角質細胞間脂質の構造を乱すことで角質細胞間経由での

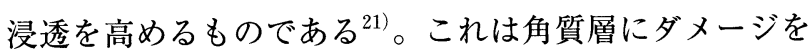
与える事であり, 促進剤自体の安全性も高くないため, 化粧品用途での利用は難しい。そうした欠点を改善させ る目的で高分子経皮吸収促進剤の開発も一方でおこなわ れている22)。角質層は疎水的であり, 親水性物質より親 油性物質とのなじみが良い。そこで西坂らは角質層と親 和性の高い油剤が容易に角質層に浸透し, 貯留すること を見いだした ${ }^{23)}$ (Fig. 5)。その油剤に薬理成分を溶解して 浸透媒体として利用できることも明らかにした。選ばれ た油郕は汎用的なものであるため, 安全性面の問題はな 


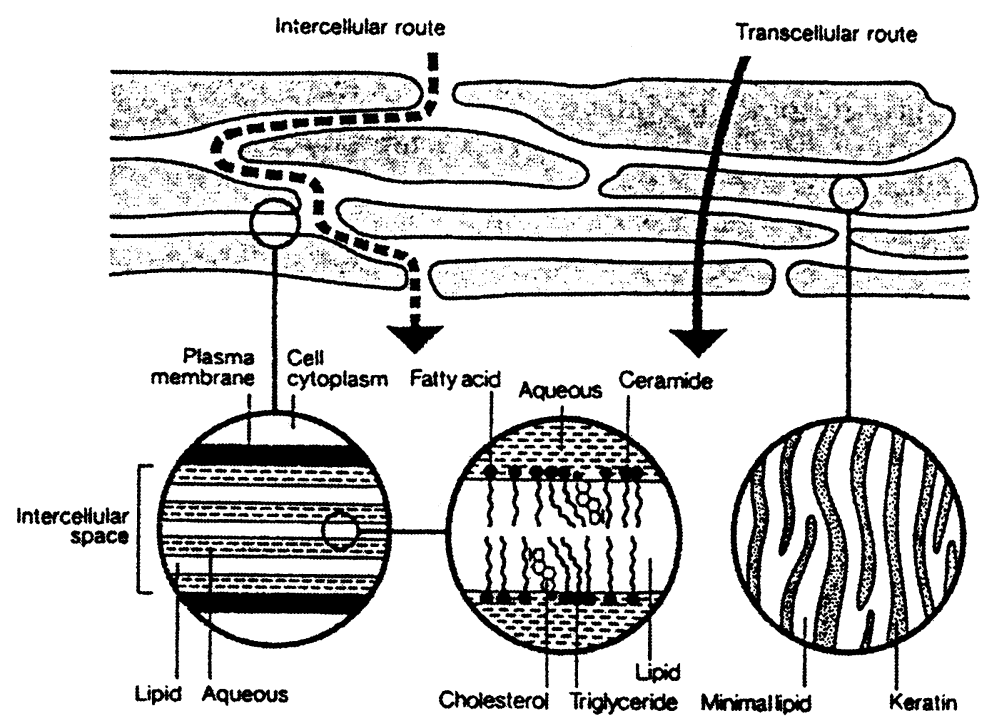

Fig. 4 Suggested Routes of Drug Penetration Through Human Stratum Corneum.

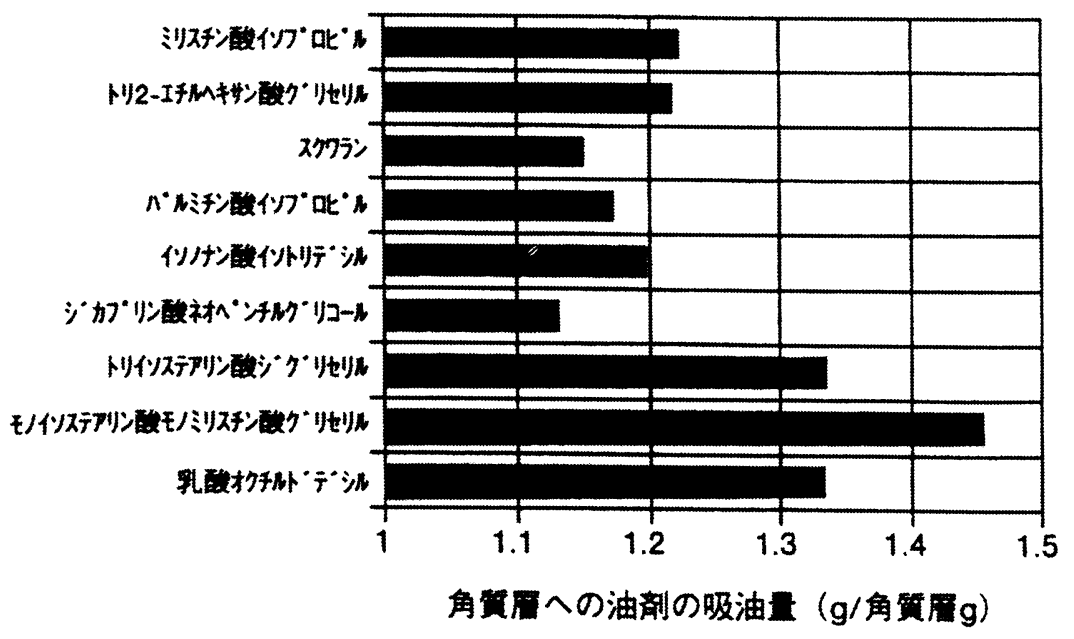

Fig. 5 Absorption of Oil into Pig Stratum Corneum.
とした「貼り薬」が心蔵病薬のための ニトログリセリン，禁煙薬の「ニコチ ンパッチ」で製剤化されてきた。香粧 品分野でもこうしたシートタイプのス キンケア化粧料が多数上市されてきて いる ${ }^{27)}$ 。薬効成分を含むゲルが塗工さ れた貼布タイプや化粧水成分を不織布 に含浸させたタイプで目元などの使用 部位にフィットした形や顔面形状に裁 断されてある。数十分〜数時間貼り続 け，有効成分の角質層への浸透やうる おいをもたらす効果を訴求している。

医薬品での経皮吸収のメリットは経 口投与の場合と比較され，直接毛細血 管に入ることにより，(1)肝臟への取り 込みによる薬効成分の分解がない，(2) 即効性が高いことが挙げられる ${ }^{28)}$ 。 従って多くの場合, 皮虐中での滞留は 必要がないため, 化粧品で求めている 皮虐への経皮吸収とは目的が異なって いる。

化粧品における薬効剤の皮膚への浸 透にも，効果を発現するために必要な 浸透部位が異なってくる。角質層中に 留めるべき成分，角質層下の表皮に留 めるべき成分, 真皮内に留めるべき成 分，血流に吸収すべき成分に分類され る (Table 4)。従って, 浸透性を評価 する上では, 必要部位で浸透ならび に，その部位での滞留性を評価しなけ れば，スキンケア化粧料として使用し

く，角質層にダメージを与えることがないため，本来の バリアー能を維持している利点をもつ。こうした油剤を 用いて乳化製剂を調製すれば，薬理効果の高いスキンケ ア化粧料が完成できる。

医薬品分野ではこれらの化学的浸透促進法に加え，物 理的浸透促進法と呼ばれる外力を利用した方法も行われ ている。電位差を起こし, 電解質の移動に合わせてイオ ン性薬物の浸透を促すイオントフォレーシス（iontophoresis ${ }^{24), 25)}$ や $1 \mathrm{MHz}$ 以上の超音波により皮膚の透過性を 変化させるフォノフォレーシス (phonophoresis) ${ }^{26)}$ があ る。今後, 香粧品分野でも活用される可能性は十分にあ ろう。

近年，経皮吸収経路を利用して，積極的治療効果を求 める経皮治療システム（TTS：transepidarmal therapeutic system）が着目されおり, 局所の抗炎症作用を目的
た時の効果発現とを結びつけることはできない。

また, 凨型の違いによる浸透性を評価する場合, それ らの処方が大きく異なっていると，高浸透性が認められ ても, 塗布した際の水分や揮発成分の蒸発や, 乳化構造 の破壊などが生じて, 例えば油郕の閉塞性による寄与な ど剤型に関連しない副次的な影響を製剤本来の効果と見 誤ってしまう可能性がある ${ }^{29)}$ 。刻型の違いによる浸透性 の評価には比較組成をそろえたり, in vitroでの浸透性

Table 4 Penetrating Position of Ingredients in the Skin.

\begin{tabular}{|c|c|c|}
\hline \multicolumn{2}{|c|}{ 皮膚上 } & 紫外線吸収剂, 皮脂膜, 抗皮脂酸化剂 \\
\hline \multirow[b]{2}{*}{ 表皮 } & 角質層 & 細胞間脂質, NMF \\
\hline & $\begin{array}{l}\text { 有刺層/顆粒層/ } \\
\text { 基底層 }\end{array}$ & 美白剤，角化コントロール剂 \\
\hline \multicolumn{2}{|l|}{ 真皮 } & しわ改善剤, 抗炎症片, 血行促進剤 \\
\hline
\end{tabular}


評価システムを構築するなど, 慎重な評価が必要であ る。

\section{$3 \cdot 2$ 高浸透を目指した製㓮化}

化粧品分野では, 有効成分の浸透性を高めるために適 した剤型の検討や様々な工夫が講じられてきた。これま で化粧料で汎用されている $\mathrm{O} / \mathrm{W}$ 型エマルション, W/O 型エマルションに対し, 高含油あるいは高含水エマル

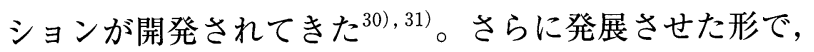
$\mathrm{W} / \mathrm{O} / \mathrm{W}$ 型や $\mathrm{O} / \mathrm{W} / \mathrm{O}$ 型 ${ }^{32)}{ }^{33)}$ の多相 (multiple) エマル ションが調製され，スキンケア特性の探索がなされてき た。多相エマルションには, (1) O/W 型, W/O 型では 得られない特殊な使用感を付与できる ${ }^{33)}$ 。(2)中間にある 油相あるいは水相によって内水相あるいは内油相が守 られるため酸素などに不安定な成分を安定に配合でき る ${ }^{34)}$ (3)内水相あるいは内油相に内包した成分を徐放でき る ${ }^{34)}$ (4)中間相の成分を極端に少量化できることが明らか にされている。

皮膚浸透性に関しては，O/W/O 型エマルションで, テルペンの浸透性をヘアレスラットを用いた拡散セルに より $\mathrm{W} / \mathrm{O}$ 型との比較で評価した報告がある。W/O 型 からのテルペンの放出が $\mathrm{O} / \mathrm{W} / \mathrm{O}$ 型より 2.5 倍早く, 30 時間後で放出が終わってしまったのに対し，O/W/O 型 は直線的に放出し続けていたことから，薬効剤を長時間 保持し, 皮膚への分配をコントロールできる剤型である ことを示していた ${ }^{34)}($ Fig. 6)。一方，W/O/W 型エマル ションでは, その内水相に尿素を含有した場合と最外層 に尿素を含有した場合で，豚皮角層に塗布した時の保湿 効果を評価したところ, 内水相に尿素を含有した $\mathrm{W} / \mathrm{O} / \mathrm{W}$ 型エマルションで高い効果を示していることを 明らかにした ${ }^{35)}($ Fig. 7)。この効果発現は，尿素が W/O エマルションの形で角層に浸透しているためであると推 定している。

乳化型化粧料とは全く異なるラメラ液晶化粧料も開発

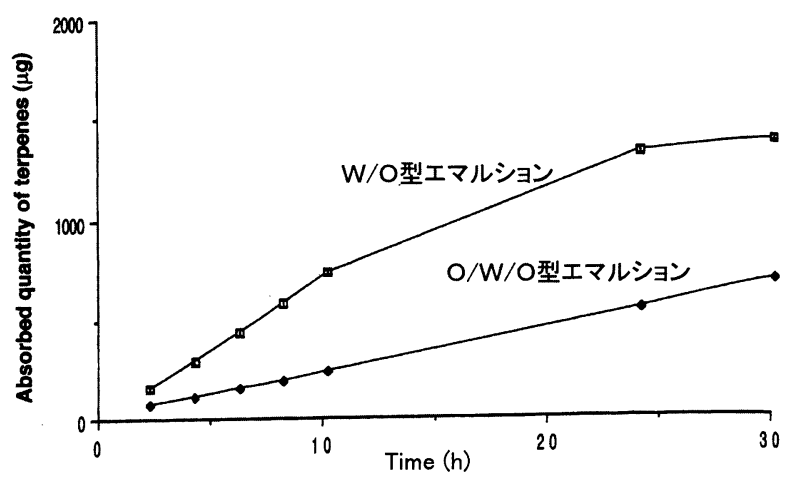

Fig. 6 Percutaneous Absorption of Terpenes Encapsulated into an O/W/O Multiple Emulsion or a W/O Simple Emulsion.

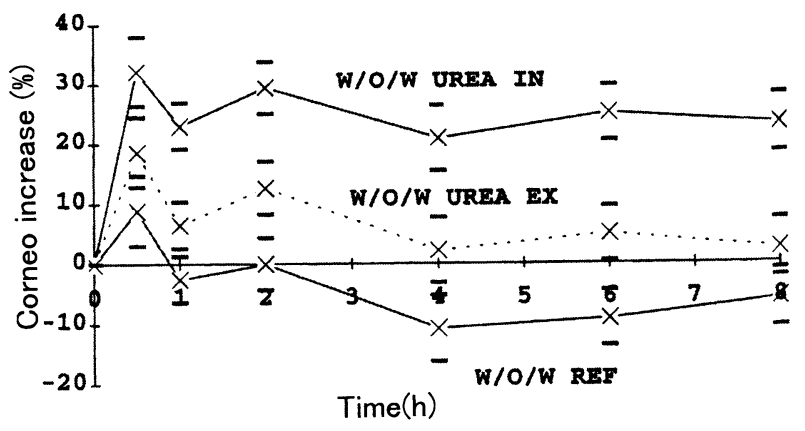

Fig. 7 Moisturization of Multiple Emulsions on Pig Skin in vivo.

されている ${ }^{36)}$ 。この集合構造は角質層内の細胞間脂質が 形成するラメラ構造と同一の集合構造となっているため (Fig.8), 皮膚に塗布した際，擬似的な角層を形成した 状態になり，O/W,W/O 乳化化粧料に見られない保湿効 果を示していた（Fig.9）。またラメラ液晶化粧料に配合 されたセラミドの浸透性は他の乳化剂型より高い角質層 浸透性を示していた（Fig. 10）。

レシチンは古くから細胞膜構成成分であることから， 生体への安全性が高い乳化剂として医薬品, 化粧品で多 用されてきた。特に連続相から隔離されたマイクロカプ セル様のリポソームを形成することから，脂溶性薬物だ けでなく，水溶性薬物の内包が可能である。レシチンの 相転移や $\mathrm{pH}$ 変化など外的環境に応じた物性を利用した コントロールリリースやドラッグデリバリー媒体 (DDS) としての用途が検討されてきた。また，リポソームの経

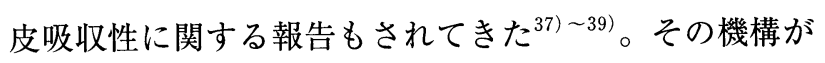

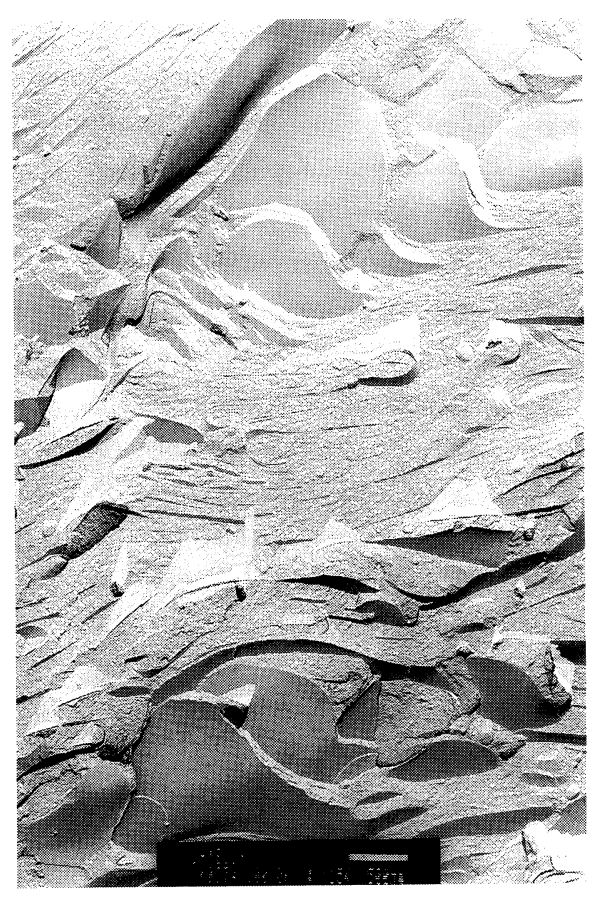

Fig. 8 Freeze Fracture Electron Microscopy of Lamellar Gel. 
明確に解明されぬまま，スキンケア化粧料においてリポ ソーム技術を導入されたため，厚生省はリポソーム製剤 を標榜するための承認基準を設定した（Table 5)。

化粧品でリポソームを扱う場合の大きな課題はレシチ ンの安定性である。常温保存される条件では, レシチン に高純度，不飽和部分を持たないことが求められる。

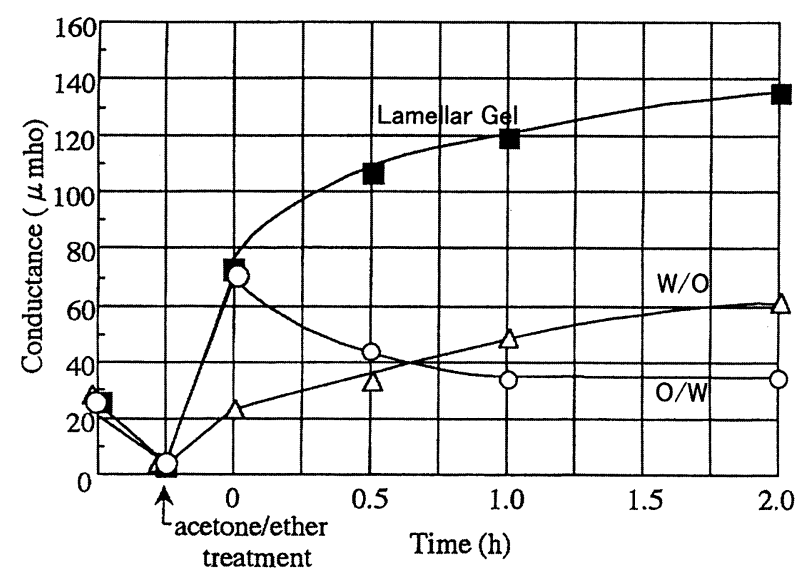

Fig. 9 Penetration of Skin Surface Conductance Values Corresponding to Water-retaining Ability of Stratum Corneum by Treatment with $\mathrm{O} / \mathrm{W}, \mathrm{W} / \mathrm{O}$ and Lamellar Gel.

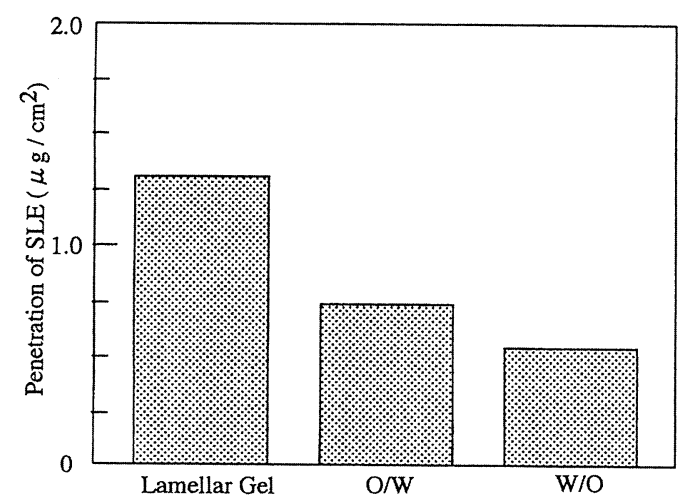

Fig. 10 Penetration of Pseudo-ceramide into Stratum Corneum Sheet, Detected by HPLC.

Table 5 Treatment of Liposomal Cosmetics by the Ministry of Health and Welfare.

1. 本取扱いは, 水素添加大豆レシチン等の配合により意図し てリポソーム等を形成させ, 保湿性の向上等を図るために 製片化したものに適用される。

2. 上記に該当する化粧品の申請に際し必要な添付資料は，次 のとおりである。

1）安定性に関する資料：当該製品流通期間中リポソーム等 が安定であることを証明する資料。

2 ) 安全性に関する資料：必要な資料は，概ね次のとおりで ある。なお，試験はすべて製品で実施したものとする。 急性毒性, 皮膚一次刺激性, 皮膚感作性, 光感作性, 変 異原性，ヒトパッチ

3.リポソーム等を形成させることにより，従来の化粧品の効 能の範囲を超えて，薬効が期待できるものについては，医 薬品又は医薬部外品として申請すること。
従って，高品質のレシチンを使用しなければならないこ とから，化粧料への製剂化にはコスト的な制約が伴うこ ととなる。

4 マイクロエマルション

\section{$4 \cdot 1$ 乳化粒子の微細化}

エマルションの粒径を微細化する試みが古くからなさ れてきた。界面化学的な特性を利用した乳化手法と機械 的エネルギーを利用した調製法に大別される。前者につ いては界面活性剤の特性を利用して油水界面張力を下 げ，弱い攪拌力でも容易に油滴粒子を小さくさせる方 法，あるいは可溶化状態にある分散質（油）の析出を生 じさせる方法がある。これらの調製方法は HLB 温度乳 化法 $\left(\right.$ 転相温度乳化法 ${ }^{40)}$, 液晶乳化法 ${ }^{41)}$, 転相乳化法 (反転乳化法 ${ }^{42)}, \mathrm{D}$ 相乳化法 ${ }^{43)}{ }^{44)}$ として知られている。 これらは特殊な機械を用いることなく調製できる利点を もつ一方で, 液晶相, D 相, 転相を生じさせる処方系で なけらばならないため，活性剤，油の組み合わせに制約 がある。

一方，機械的エネルギーを利用した調製法は高せん断 型ホモミキサー, 超音波型ホモジナイザー, 高圧ホモジ ナイザーに分類され，容易にサブミクロンの粒子径を得 ることができる。この手法は大きな液滴を機械力で細か く分散していくため，その破砕エネルギー及び，処理時 間に大きく依存して粒径分布が変化する ${ }^{45)}$ 。しかし，こ の製造法では高せん断により高熱を発生するため，耐熱 性の低い物質には適さない点や，高分子などが切断され てしまう場合がある。

機械的エネルギーを評価する指標として「せん断力」 があげられる。高圧ホモジナイザーのみならば出力圧力 で比較されるが, 高せん断型ホモミキサー等との共通の パラメーターとして「最大せん断速度」が算出され, 機 械力の比較ができる（Fig.11）。その比較から高圧ホモ ジナイザーは高いエネルギーを与えることができる (Fig.12)。それに加え，より高い圧力の出力ができるよ うになったため，マイクロフルイダイザーなどの性能が 飛躍的に進歩している。

高圧ホモジナイザーの利用は，粉体の分散（disperse）と油の乳化（emulsify）に分類できる。分散で はインクトナーなどで使用されている。乳化においては 医薬品分野で脂肪乳剤の製造法としてょく利用されてき た。高圧ホモジナイザーの利用の難点はその製造速度に 限界があるため，香粧品分野での利用は遅れていたが， 最近これを解決した化粧品が上市されてきた。 


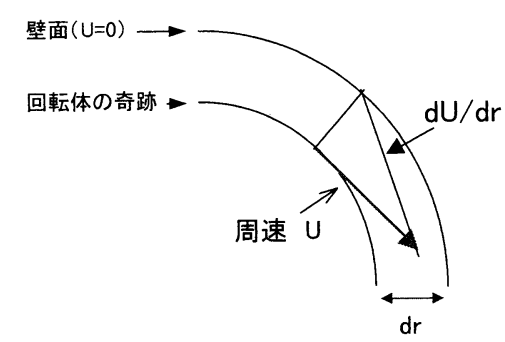

高せん断型ホモミキサー

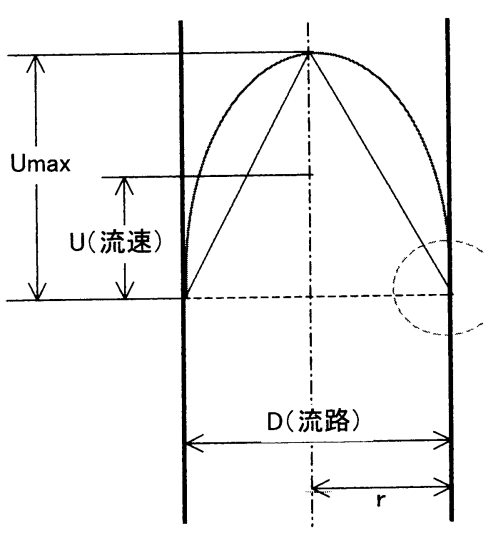

高圧ホモジナイザー

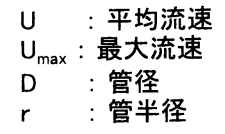

最大剪断速度 $d U \max / \mathrm{dr}$

$\mathrm{U}=\left(\mathrm{U}_{\max } / \mathrm{r}^{2}\right) \mathrm{x}^{2}$

$\begin{aligned}\left(d U_{\max } / d r\right)_{\max } & =\left(2 U_{\max } / r^{2}\right) x \\ x & =r ;\left(d U_{\max } / d L\right)\end{aligned}$

Fig. 11 Calculations of Shear Rate.

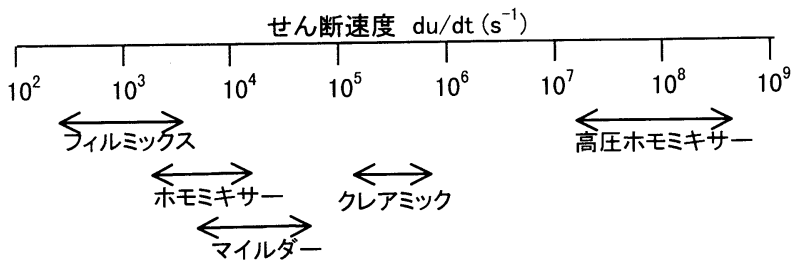

Fig. 12 Shear Rate of Emulsifiers.

\section{$4 \cdot 2$ 乳化粒子の微細化のメリット}

\section{$4 \cdot 2 \cdot 1$ 外 観}

乳化粒子は $100 \mathrm{~nm}$ 以下の粒径を有すると, 半透明か ら青みを带びた透明，無色透明な外観を呈するようにな る。この現象は乳化粒子が可視光波長より小さくなった 時に適用されるレイリー散乱に基づいている。単位強度 の白色光を粒径 $\mathrm{d}$ の粒子に照射した時の散乱光の動径分 布は Rayleigh 式（式 1) で示され, 全 $\theta$ について積分し た全散乱光 $S$ は式 (2) で示される。すなわち $S$ は d の 6 乗に比例して急激に増加する。同一組成で調製した場 合は, 乳化粒子径が大きくなれば粒子数が減少してくる ため, 実際の $S$ は $d$ の 3 乗に比例していく。このこと から，マイクロエマルションが調製できても，粒径のわ ずかな変化が外観透明性の変化として反映されてしまう ため, その安定性維持が重要な課題となってくる。ま た，粒径を一定にした場合， $S$ は光の波長の 4 乗に反比 例してくることから，短波長の光の散乱強度が長波長側 より高くなってくる。乳化粒子径により透明性に青みが 帯びてくるのはこのためである。

$$
\begin{aligned}
& I_{\theta}=\frac{9 \pi V^{2}}{2 R^{2} \lambda^{2}} \frac{m^{2}-1}{m^{2}+1}(1+\cos \theta) \\
& S=24 \pi^{3} \frac{m^{2}-1}{m^{2}+1} \frac{V^{2}}{\lambda^{4}}
\end{aligned}
$$

$\theta$ : 入射光と散乱光を観測する方向との間の角度

$$
\begin{aligned}
& I_{\theta}: \theta \text { 方向における散乱光の強さ } \\
& V: \text { 粒子の体積 }(d: \text { 粒子の半径 }) \\
& R: \text { 粒子と観測点間の距離 } \\
& m: \text { 粒子の屈折率 }
\end{aligned}
$$

\section{$4 \cdot 2 \cdot 2$ 乳化安定性}

乳化粒子径が小さいほど, 乳化安定性は向上する。乳 化系の分離現象であるクリーミングは乳化粒子と連続相 の比重差で生じる。この時の粒子の運動速度は stokes の沈降速度式（式 3) で示され, 粒子直径 $(d)$ を小さ く, 連続相の粘度 $(\eta)$ を大きくして, $V$ を小さくれ ばよいことがわかる。乳化粒子は周囲に存在する連続相 分子の衝突でブラウン運動を引き起こしている。このブ ラウン運動による拡散速度が沈降速度を上回るとクリー ミングが抑制される。連続相を水とした時, 乳化粒子径 が約 $0.1 \mu \mathrm{m}$ 以下でブラウン運動の効果が生じる。従っ て, 乳化粒子単体の安定性が高ければ, 乳化系全体での 安定性は良好であることがわかる。

$$
\begin{aligned}
V & =\frac{g d^{2} \Delta p}{18 \eta} \\
V & : \text { 沈降速度 } \\
d & : \text { 粒子の直径 } \\
\Delta p & : \text { 分散相と分散媒の密度差 } \\
\eta & : \text { 分散媒の粘度 } \\
g & : \text { 重力 }
\end{aligned}
$$

\section{$4 \cdot 2 \cdot 3$ スキンケア効果}

エマルション粒子が小さくなると, 皮膚への浸透性が 高くなる報告がなされている。

$0.4 \%$ のンドメタシンを油相に含有した平均粒径 87 $\mathrm{nm}$ のマイクロエマルションと $10 \sim 100 \mu \mathrm{m}$ のマル 
ションを浮腫ラットに塗布すると, マイクロエマルショ ンが優位に抗炎症効果を示していた ${ }^{46)}($ Fig.13)。また, ビタミン Eを含有したマイクロエマルションが, O/W エマルションより浸透性が通常高い W/O エマルション より浸透速度が早くかつ浸透量が多かったことを報告し ている ${ }^{47)}$ 。しかし，この現象は薬剤のみの浸透性が向上 するためなのか, エマルションの浸透性が向上している ためなのか, メカニズム的な部分は不明確である。

液晶構造をとったクレンジング剤が製剤化されてい $3^{48)}$ 。このクレンジング剤では皮膚塗布後のマッサージ で水分が蒸散し, 油相が連続相となって油性污れを良好 に溶かしこむ。次の洗い流し工程では，水の添加によ り, $\mathrm{D}$ 相 $\rightarrow \mathrm{O} / \mathrm{D}$ 相 $\rightarrow \mathrm{O} / \mathrm{W}$ 相へと相変化する。この過

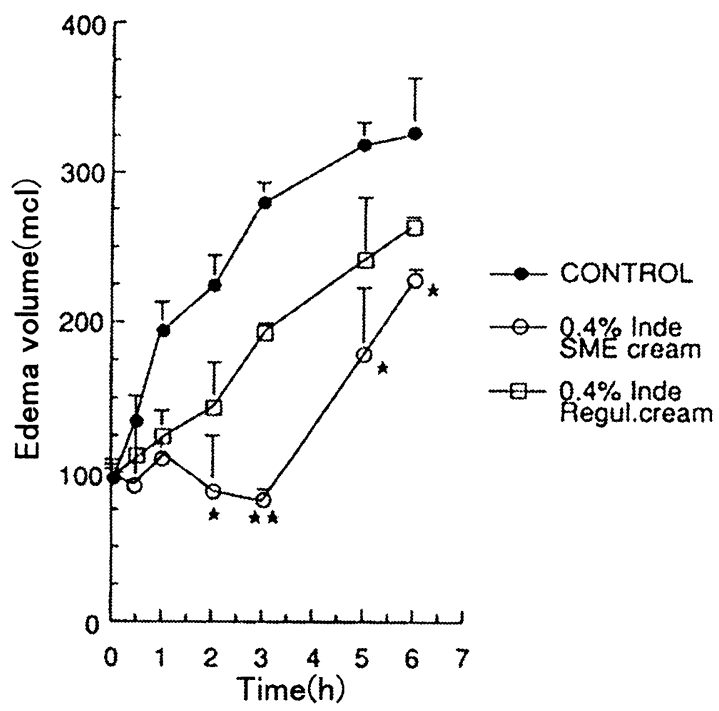

Fig. 13 Antiinflammatory Activity of Topical Indomethacin in Different Vehicles.

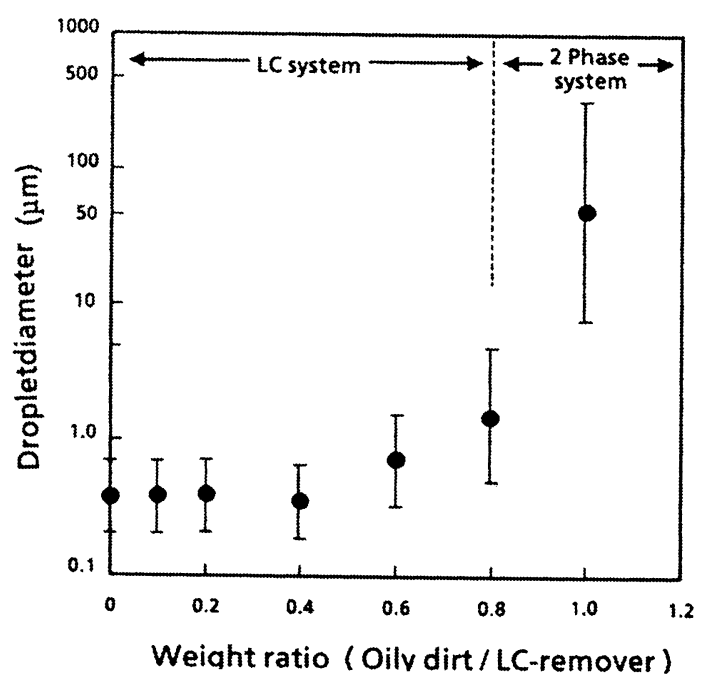

Fig. 14 Droplet Diameter of Emulsions Formed in Rinsing Process of Liquid Crystal Remover with Addition of Various Amounts of Oil.
程での油と D相間の界面張力が著しく小さいことから， 外部からわずかなエネルギーの供給だけで微細な乳化粒 子が形成される。微細な乳化粒子はブラウン運動により 拡散性が良いために, 容易に水で洗い流される(Fig.14)。 一方，洗い流し時に液晶を経由しない系は，比較的大き な液滴を形成し，乳化をおこしてもすぐに皮膚に油膜と なって付着してしまう。微細化エマルションはこうした 面でも優位な特性を発揮している。

\section{5 おわりに}

化粧品での製剤型の役割は, 油分, 保湿剤, 水分を基 本成分として, 適切な使用感を与えながら, 保湿効果を 与えることにあった。それに加え近年, 皮膚科学研究が 進展するにつれ，しみ，しわなどの発生メカニズムが解 明され，それらを予防したり改善する物質が発見されて きた。しかし，肝心なことはこれらが適切な部位に浸透 しなければ効果が発現されないことである。また中には 不安定な物質である場合もある。化粧料で用いられる殽 型はこうした物質の欠点を補い, 必要な部位へ浸透さ せ，持続的な効果をもたらすキャリアーとして重要性が 増してきた。

限られた活性剤, 油剤の組み合わせの中で, 物理化学 特性を利用したり，機械的エネルギーを利用することで 様々な乳化製剤が生み出されてきた。今後はこれらの製 剂が, 有効基剤の機能を最大に発現されるようにアレン ジされていくことであろう。

\section{文献}

1) 野村利夫, (1999) 化学と工業, 52, 275.

2）近藤秀俊, 沢 清隆, (1995) Fragr. J., 23 (4), 97.

3）林 利彦, 西山敏夫, 百武昌夫 (1991) 表面, 29, 1.

4）須藤雅夫, (2000) 化学工学, 64, 84.

5）芋川玄爾, (2000) Fragrance J. 臨時増刊 27.

6) Jokura, T., Ishikawa, Y., Tokuda, H., Imokawa, G., (1995) J. Invest. Dermatol., 104, 806.

7) Ishii, H., Mikami, N., Sakamoto, J., (1996) J. Soc. Cosmet. Chem., 47, 351.

8）吉原 寛, 金子大介, (1996)Fragr. J., 24 (7), 51.

9）塘 久夫, 宇津木利明, 河野純一, 石田篤郎, 林 静 夫 (1997) J. Soc. Cosmet. Chem. Japan, 13, (2), 37.

10）西山聖二, 小松日出夫, 田中宗男, (1983) J. Soc. Cosmet. Chem. Japan, 17, (2), 116.

11）河野善行, (2000) 第 20 回油化学酸化セミナー p.23.

12) Imokawa, G., Akasaki, S., Kuni, O., Zama, M., Kwai, M., Minematsu, Y., Hattori, M., Yoshizuka, N., Kawamata, A., Yano S., Takaishi, N., (1989) J. Dis. Sci. Tech., 10, 617.

13) Werts, P.W., Swartzendruber, D.C., Kitko, D.J., Madison, K.C., Downing D.J., (1989) Invest. Permatol., 93, 169. 
14) Iwai, H., Fukazawa, J., Suzuki, T., (1986) J. Colloid Int. Sci., 183, 13.

15) Abraham, W., Wertz, P.W., Landmann, L., Downing, D.T., (1986) J. Invest. Dermatol., 87, 582.

16）鈴木敏幸，芋川玄爾，川俣 章，(1993）日化, 1107.

17) Barry, B.W. J., (1987) Controlled release, 6, 85.

18）小木兽太郎, (2000) 薬学雑誌, 120, (4), 328.

19) Stoughton, R. B., McClure, W.O., (1983) Drug Develop Ind. Pherm., 9, 725.

20) Yano, T., Higo, N., Fukuda, K., Tsuji, M., Noda, K., Otagiri M., (1993) J. Pharm. Pharmacol., 45, 775.

21) Hadgraft, J., Guy, R.H., (1989) Transdermal Drug Delivery, Marcel Dekker, Inc., New York, p.197.

22）長瀬 裕，秋元倫子, (2000) 高分子, 49, 137.

23）西坂崇宏, 山崎誠司, (1998) Drug Delivery System, 13 (5), 347.

24) Sanderson, J. E., Caldwell, R. W., Hisao, J., Dixon, R., Tuttle, R. R., (1987) J. Pharm Sci., 76, 215.

25) Bommannan, D.B., Tamada, J., Lung, L., Putts, R.O., (1994) Pharm. Res., 11, 1809.

26) Meidan, V.M., Docker, M., Walmsley, A.D., Irwin W., (1998) J. Pharm. Res., 15, 85.

27）山下重樹, (1999) Fragrance J., 27, (2), 86.

28）山下明泰, (2000) 化学工学, 64, (2), 81.

29) Dahms, G.H., (1995) Seifen-Oele-Fette-Wachse 121, 10,730 .

30）鈴木裕二, 塘 久夫, (1987) 油化学 36, 588 .

31）山口道広, 熊野可丸, 戸辺信治, (1991) 油化学, 40, 491.

32) 作山 秀, 酒井裕二, 福田泰博, (1999) 第 38 回油化学 討論会 講演予稿集, 名古屋, p.126.
33）関根知子，草刈 建，松崎文昭，梁木利男，(1999）第 38 回油化学討論会 講演予稿集, 名古屋, p.125.

34) Laugel, C., Baillet, A. B., Ferrier, D., (1998) Int. J. Cosmet. Sci., 20183.

35) Dupuil, L., (1996) Seifen-Oele-Fette-Wachse, 122, 658.

36) Iwai, H., Fukazawa, J., Suzuki, T., (1998) Int. J. Cosmet. Sci., 20, 87.

37) Mezei, M., Glasekharam, V., (1980) Life Sci., 26, 1473.

38) Jayaraman, S.C., Ramachandran, C., Weiner, N., (1996) J. Pharm. Sci., 85, 1082.

39）奥 直人，岩永一範，山下伸二, (1997) J. Soc. Cosmet. Chem. Jpn., 31, 254.

40) Shinoda, K., Saito, H., (1969) J. Colloid Interface Sci., 30, 258

41) Suzuki, T., Takei, H., Yamazaki, S., (1989) J. ColloidInt. Sci., 129, 491.

42) Sagitani, H., (1981) J. Am. Oil Chem. Soc., 58, 738.

43）鷺谷広道, 服部孝雄, 鍋田一男, 永井昌義, (1983) 日 化, 1399.

44) Sagitani, H., Hirai, Y., Nabeta, K., Nagai, M., (1986) J. Jpn. Oil Chem. Soc., 35, 102.

45）森田正道, (1991) 油化学 40, 58.

46) Friedman, D., Schwarz, S., Weisspapir, M., (1995) J. Pharm. Sci., 84, 324.

47) Ziegenmeyer, J., (1982) Dermal and Transdermal Absorption, Brandau, R. and Lippold, H., eds, Stuttgart: Wissenschaftl Verlagsgesellschaft pp 73-86.

48) Suzuki, T., Nakamura, M., Sumida, T., (1992) J. Soc. Cosmet. Chem., 43, 21. 


\title{
餐合論文 ポリシロキサン三次元架橋体の開発と 化粧品への応用
}

\author{
栗林さつき \\ 株式会社コーセー研究本部 開発研究所 開発研究グループ（テ 174-0051 東京都板橋区小豆沢 1-18-4）
}

化粧品には，皮膚に柔軟性を与える等の目的で，様々な液体油が広く応用されている。これらの液体油をゲル化し， 構造粘性を付与することは, 化粧品製剤の安定化のためにも非常に重要な技術である。また近年は, 油剤としてジメ チルポリシロキサンが沉用されている。このジメチルポリシロキサンは, 油っぽさや゙たつきがなく, 且つ軽いのび, 高い撥水性などの特長を有する油剤である。しかしながら, これら液体油のゲル化澈, 特にジメチルポリシロキサン のゲル化剂は数が少なく，化粧品に安定に配合することは困難であった。

そこで，我々は新たに，ジメチルポリシロキサン中で膨潤してソフトゲルを形成する，ポリシロキサン三次元架橋 体を開発した。また，これらの架橋体に化学的修飾を行うことで, ジメチルポリシロキサン以外の油凨, 例えば炭化 水素油，エステル油，グリセライド油に対してのゲル化剤や，W／O型ゲルエマルションをつくることができた。

本稿では，これらいくつかのポリシロキサン三次元架橋体の構造とその特性，そして化粰品への応用例を紹介する。

(連絡者：栗林さつき) Vol.1, No.3, 247 (2001)

\section{縔合諞文 化粧品におけるスキンケア製剂の役割}

\section{岩井秀隆}

\section{花王株式会社 スキンケア研究所}

化粧品における製剤の役割は皮膚の保湿にあり，適切な感触に調整される。W/O 型， $\mathrm{O} / \mathrm{W}$ 型が一般的であり，使 用感で使い分けされてきたが，近年は様々な乳化製剂が開発され，その使い分けはあいまいになってきた。皮膚の保 湿は単に水の供給によるのではなく，天然保湿因子成分，皮脂，七ラミドをバランスよく角層に供給しなければなら ない。従って，これらを含有したスキンケア化粧料が必要となる。最近は皮膚科学研究の発展が著しく, 肌の悩みと されるしみやしわを予防したり改善する基剤が発見されてきている。重要なことは，これらの成分が皮䖉内の適切な 個所に供給されなければならない。またそれらの基剤には大気中で不安定な場合もある。乳化製剤はそれらのキャリ ヤーとしての役割を求められてきた。界面化学物性の利用や新規な機械を用いて多層エマルションやマイクロエマル ションが調製され，基荗の浸透性を向上させる期待が持たれている。 